CURRENT RESEARCH JOURNAL OF HISTORY

(ISSN -2767-472X)

VOLUME 03 ISSUE 01 Pages: 34-39

SJIF IMPACT FACTOR (2021: 5. 505)

OCLC - 1243560778 METADATA IF - 6.458

Crossref do

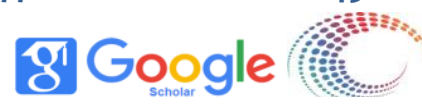

metapata

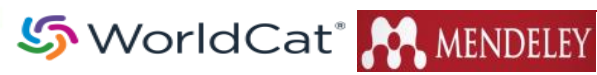

Publisher: Master Journals

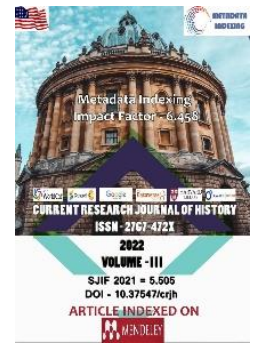

Journal Website: https://masterjournals. com/index.php/crjh

Copyright: Original content from this work may be used under the terms of the creative commons attributes 4.0 licence.
Research Article

\section{ALLA - AN ANCIENT MASTERPIECE OF SINGING ART (COMPARATIVE ANALYSIS)}

Submission Date: January 09, 2022, Accepted Date: January 20, 2022,

Published Date: January 30, 2022

Crossref doi: https://doi.org/10.37547/history-crjh-03-01-08

\section{Radjabova Nodira Mehmonovna}

Researcher, Deputy Director, Department of General History, Bukhara State University, Academic Affairs of the Bukhara specialized Boarding School of makom art named after Abdurauf Fitrat, Bukhara, Uzbekistan

\title{
ABSTRACT
}

This article examines the history of singing art with the birth of mankind, the influence of the song genre on the spiritual and moral state of peoples, the dynamics of the process of transferring singing art from generation to generation over the centuries. In addition, the genres of songs have a long history and have been passed down from generation to generation for centuries. The origins, stages of development and features of the song genre "Alla" are discussed. Many aspects are analyzed, such as the fact that the genre of Alla's singing is based on folklore, the uniqueness of this type of song, its narration in simple and understandable language. The article systematically describes the history of the song genre, its artistic features, philosophical and spiritual features. The stages of the genre of the song "Alla", the features of each stage, the role of children in the spiritual and aesthetic education of the cradle are scientifically substantiated. The text of the article summarizes the opinions of various experts in the field of the song genre "Alla". In conclusion, the article reveals the importance of the development of the song genre in the conditions of new thinking, the relationship between mother and child. Approaches to the question of the genre of the song differ, and it was analyzed that discussions on this issue continued both during the years of Soviet power and during the years of independence. It is shown that the height of a person's spirituality can be an important factor in raising a child at the level of the song genre that mothers sing, rocking the cradle at birth. It is revealed that in the genres of Alla songs it has become a tradition to pamper a child and compare him with powerful forces and historical figures. Alla song genre takes into account the influence of Asian and European natural factors. The importance of the mother's level, the pleasantness of the sound of the words used instead of them, and so on as the songs of God reach the baby in the cradle. At the end of the article, scientifically based recommendations are given for further popularization and improvement of the song genre. 
CURRENT RESEARCH JOURNAL OF HISTORY

(ISSN -2767-472X)

VOLUME 03 ISSUE 01 Pages: 34-39

SJIF IMPACT FACTOR (2021: 5. 505)

OCLC - 1243560778 METADATA IF - 6.458

Crossref do

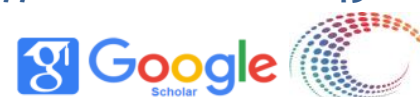

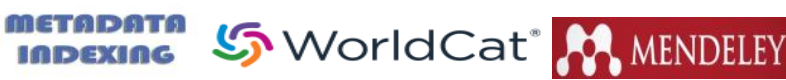

Publisher: Master Journals

Methods: to reveal the essence and content of the small study, such methods and techniques as consistency and structure, analysis and synthesis, comparative analysis, objectivity and objectivity, historicity and periodicity were used.

Results: 1) The features of the song genre in Uzbek and world singing art are analyzed.

2) The Alla song genre has become widespread among all peoples of the world and is an important factor in the upbringing of children.

3) The opinions of domestic and foreign researchers created in the field of the song genre, Alla, were studied and the scientific tasks to be performed in the future were determined in this regard.

Discussion: The genre of the song has its roots in the deep history of mankind. It has been passed down from generation to generation over time. However, the most important aspect of this genre that has caused controversy is the tendency to modernize in the process of passing the test of time.

\section{KEYWORDS}

Song, folk songs, alla, aesthetic taste, melody, musical instrument, ethnography, ethnopedagogy, tradition, ritual, performance, art.

\section{INTRODUCTION}

Uzbek folk songs are composed of various genres, and all the rituals, traditions and customs from a person's birth to the last days of his life are the sorrows, dreams and aspirations of a person's soul, his attitude to reality, his feelings in the network of the heart are embodied in songs. According to sources, the diversity of song genres, their commonality and originality have historically developed over many centuries. The analysis and study of these genres, as well as their scientific evaluation, is one of the most important spiritual needs of the time.

For example, "alla" is one of such genres of song.

As one of the most common traditional genres of lullabies for children from the age of five, it is important

to note that all the peoples of the world have lived for centuries in life and have undergone transformational processes at every historical stage. This article examines the evolution of song genres in the life of the peoples of the East and West. Singing "Alla", the mother's love is sung, and the expressions of the heart in her heart are transmitted to the child. There is no people, nation or ethnic group in the world that does not sing in its own language... Such songs, called "baiki" or "bayushki" in Russian, "khuvdilar" in Turkmen, "ley-ley" in Azerbaijani, "alli-bally" in Tatar, "heya-heya" in Karakalpak, "ninni" in Turkish, "lolo" in Persian, "wiegleid" in German, are known in French as "bexeus", and in Uzbek and Tajik as "alla" and "allo." Consequently, "Alla" is a somewhat joyful song of the 
CURRENT RESEARCH JOURNAL OF HISTORY

(ISSN -2767-472X)

VOLUME 03 ISSUE 01 Pages: 34-39

SJIF IMPACT FACTOR (2021: 5. 505)

OCLC - 1243560778 METADATA IF - 6.458

Crossref do
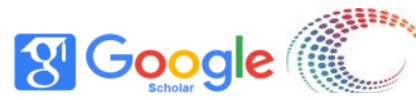

metดpata

5) WorldCat

Publisher: Master Journals

mothers of the world, but when appropriate, it is a somewhat sad, sacred song.

\section{THE MAIN FINDINGS AND RESULTS}

According to its socio-aesthetic meaning, "Alla" performs two functions: the first is to put children to sleep (the word "alla" literally means to put children to sleep). Such rubbing or falling asleep is manifested in the process of singing.

At the same time, the second function of "alla" is its educational and aesthetic essence: this is a property of alla, resulting from his emotional sensitivity, introducing the child to life in melody, which does not allow him to understand the meaning of life through melody. Thus, the discovery is aimed at educating aesthetic taste. Abu Ali ibn Sina noticed this feature of "Alla" a thousand years ago and said: "There are two things a child has to do to become a customer. One is to shake the baby slowly, and the other is music and singing, which have become a habit of putting him to sleep. Depending on how much you take of these two, your child's body and body will develop a talent for music. Emphasizing that the "slow shaking of the child" is associated with physical activity, the Supreme Judge generally states that vibration is not limited to, say, motion sickness, but can be performed by swinging or sitting with both legs side by side. the child on the pillow put on the bed, to say alla, it also meant shaking when he got up, hugged the child or said "Alla" when the mother slapped the child on the shoulder with one hand.

But these processes can be performed without the help of a swing, and the child falls asleep. The fact is that these processes are closely related to the ethnographic characteristics of each nation. For example, in Uzbek or Tajik, the melody of Alla is in harmony with the balance and rhythm of vibration, and the vibration of an object, be it a cradle or a swing, is strictly in harmony with the melody of "Alla". There is information that the French sang to the accompaniment of a rattle. Although the Uzbeks also have a tradition of attaching a rattle to a cradle or swing, but the sound is accompanied by a vibrating rhythm, and the French differ in that the melody is accompanied by a rattle.

Abu Ali ibn Sina's views on God are invaluable in determining the genesis of the genre.

The significance of the gods at the time of Ibn Sina not only in Central Asia, but also among the peoples of the Middle East, where he traveled, the widespread use of the term "balu-balu" among the Turkic peoples is confirmed by the information in "Devonu Lugotit Turk" that it is widespread as an independent genre with its traditional features. Gods are usually spoken about from the moment a baby is breastfed until the age of three. The gods are closely related to children of this age, and this feature is unique to lullabies. It is no coincidence, therefore, that the gods are associated with breast milk and are regarded as "a song soaked in milk and full of love." Yes, God has the clarity and purity of breast milk, which is why it is so sacred. Add to this the innocence, purity, innocence, beauty, purity and impurity of the baby, and the deities will be sanctified again. "Alla" is a song for life, which is passed down from generation to generation by thousands of mothers, embroidered and connected by a chain of maternal love and consent. The reason why the gods live so long is because they shine with a mother's heart and a woman's sadness. In particular, the Tajik (shirushakar) style of the gods of Bukhara, sung by the women of this oasis for centuries, is popular among the people.

Allo megum baroyaton, 
Dar gavoraho saroyaton.

Beshikdagi bir gulim, alla yo alla,

Sayrab turgan bulbulim, allayo alla.

Allo allo gulam boshed,

Sahar xez bulbulam boshet.

Beshikdagi bir gulim, alla yo alla,

Sayrab turgan bulbulim, allayo alla.

Allo allo guli qoqo,

Ki qurbonat shavad bobo.

Beshikdagi bir gulim, alla yo alla,

Sayrab turgan bulbulim, allayo alla.

Allo allo guli behi,

Ki qurbonat shavad bibi.

Beshikdagi bir gulim, alla yo alla,

Sayrab turgan bulbulim, allayo alla.
The same feature ensured that the gods were liked not only by children, but also by adults, so that they were sung and loved in every home.

So, what kind of spiritual need did God have? The answer to this question is as follows: "The mother, with her innate sensitivity, understood that the child needed only a song, a soothing, bright and monotonous song. So the form "alla" appeared. These maternal feelings told me what the gods meant: he had the whole rise of motherhood in him." The songs "Alla" cannot be imagined without the world of mothers, their feelings, their worries, but all this is not in the form of instinctive innate feelings, but as a life experience created by several generations of mothers who have lived for thousands of years, their numerous mistakes, their separation have become a bitter lesson born of their grief. In this sense, the gods are "not the result of the instinctive activity of mothers, but the product of social experience, social consciousness." They emerged as an original, immortal poetry, the beginning of all literature, when the mother-poet and the worker-educator united in one image. After all, maternal love and generosity, pain and suffering, dreams and desires, love and emigration, joys and sorrows, separation mania grow in the gods step by step. Russian theology characterizes this as three stages of maternal feelings, distinguishing them from each other in such a way that it can be seen in Uzbek gods.

Scientific works devoted to the Uzbek gods contain information about their division into three stages. In such deities, the expression of the environment surrounding the child is exaggerated, more precisely, at the first stage, a cradle, a swing, etc. are described.

At the second stage, thoughts about the fate of the child deepen against the background of the mother's personal experiences: although thoughts revolve 
CURRENT RESEARCH JOURNAL OF HISTORY

(ISSN -2767-472X)

VOLUME 03 ISSUE 01 Pages: 34-39

SJIF IMPACT FACTOR (2021: 5. 505)

OCLC - 1243560778 METADATA IF - 6.458

Crossref $d$
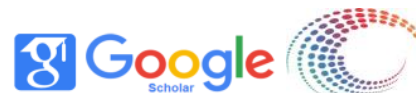

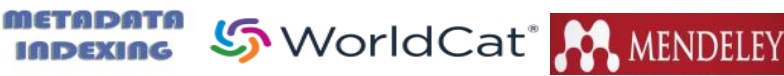

Publisher: Master Journals

around the child, he is also hindered by feelings of motherhood.

At the third stage, the mother's heartbeat deepens in the gods, and now she is involved in the whirlpool of her emotions. She is preoccupied with herself, she forgets that she has a child, she sings in a soft, but a little tired monotonous tone that flows from her heart, her pain and worries, as if this monotonous melody calms her. There are many such deities in Uzbek idolatry. The reason for this is the paucity of the repertoire of Uzbek mothers, and therefore it is incorrect to explain that whenever a song comes to her mouth, she sings it with the help of Alla. Here is the conclusion of the folklorists that with the enrichment of the mother's repertoire, when the number of alli in it reaches 3-7, a stage of specialized alla is formed, and at the same time the mother becomes a prisoner of her feelings. Based on this logic, it is necessary to explain the reason for the large number of such allas in Uzbek idolatry. Although it is more difficult to find such professional singers today, there are always 2-3 singers. For example, in the "Uzbek folk songs of Allayo alla" by Akhunjon Safarov, alla allagoi are called nanogoi. The thinkers of Navoi, as the great thinker of Navoi acknowledged in his work, were influenced by the creation and distribution of such alla, because they were specialized deities of that time. "Alla" is simply sung. They just can't be said. Monotonous (the same) the tone is a common feature of all Uzbek songs "alla". But the monotony of the tone depends on the mood and mood of the mother during the performance. While the mother's mood is tenderness and tenderness in the monotonous tone of the song "alla", she is prone to sadness and sadness when she is in pain.

In both cases, this monotonous tone affects the soul of the child, calms the heart, elevates it. In the first case, the ground is laid for the growth of the child, and in the second case, it is the basis of the child's mental frustration, which, of course, leaves its imprint on the character of the child as he grows up.

This is not the word of the song "alla" for a child, this is a melody. He really doesn't understand that word yet. The words "Alla" are important for a mother: it is the cry of a mother's heart. The melody of the same tone begins to serve as the first basic satisfaction of the spiritual needs of the child. Because "From the first month, the child demonstrates the ability to perceive music - rhythm and melody: but only the rhythm of the exchange of simple sounds suits him." However, this monotonous melody ensures the compositional integrity of the song "alla" only in the presence of various movements. Because in any case, the songs of "alla" are inextricably linked with both physical and mental activity. While physical activity is an important means of stimulating the continuous growth and development of the child, the monotonous melody of the song "alla" is a channel connecting this physical development with spiritual development and serving to activate the mental activity of the child.

It should be noted that in Uzbek folklore, the compositional integrity of the song "alla" in the unity of the word, melody and action, in the logical relationship of these words has not yet entered scientific practice.

In particular, M.Alavia "Alla, although it consists mainly of fours, sometimes when the song "alla" is excited, she continues and adds other verses, and several quatrains close to each other. In this way he expresses his wishes and aspirations" " he said. Indeed, a quartettype ensemble is the leading component of the Uzbek songs "alla", but this does not mean that all Uzbek songs "alla" are quatrains. Because in the repertoire of Uzbek mothers there are only gods in the form of 
CURRENT RESEARCH JOURNAL OF HISTORY

(ISSN -2767-472X)

VOLUME 03 ISSUE 01 Pages: 34-39

SJIF IMPACT FACTOR (2021: 5. 505)

OCLC - 1243560778 METADATA IF - 6.458

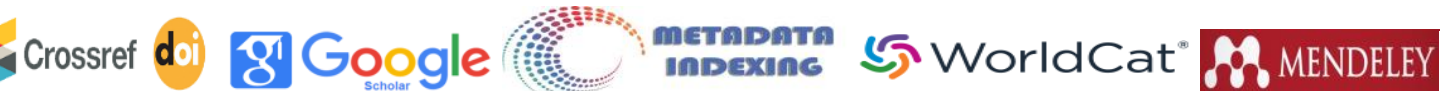

2. Alavia M. Uzbek folk ritual songs. Tashkent: “Fan”, 1974. - 353 p.

three, five, six, seven and eight, as well as "alla" with a
single ideological and aesthetic meaning, consisting of several objects in the form of three, five, six, seven and eight. There are also problems. This kind of strophic diversity is the result of the mother's mood in the situation when she sings, and depends on the weight and direction of the intention that is supposed to be expressed in this mood. Uzbek songs "alla" have such an internal logic that ensures the unity of movement, melody and content in a certain gesture.

Uzbek songs "alla" are a valuable material in the study of folk ethnography and ethnopedagogy. There are a number of children's rituals in them. It should be noted that the execution of the gods was carried out more actively in the past and was ignored in Soviet times.

\section{CONCLUSION}

The reason for this can be explained by the fact that mothers are equal to men in public life, and the upbringing of children acquires a social spirit. Nevertheless, the songs "alla" have been passed down from generation to generation through mothers for centuries. Each region has a sense of the gods, as well as local features. In particular, the songs "alla", which became a song in the Uzbek and Tajik languages of the Bukhara oasis, were performed in both languages. Or sugar gods have been an important factor in the upbringing of thousands of generations over the centuries. In the future, the Bukhara oasis will play an important role in the development of the singing art in the "alla" area.

\section{REFERENCES}

1. Abu Ali ibn Sino. "Tib qonunlari". I book, Tashkent, 1959. - 293 pages. 